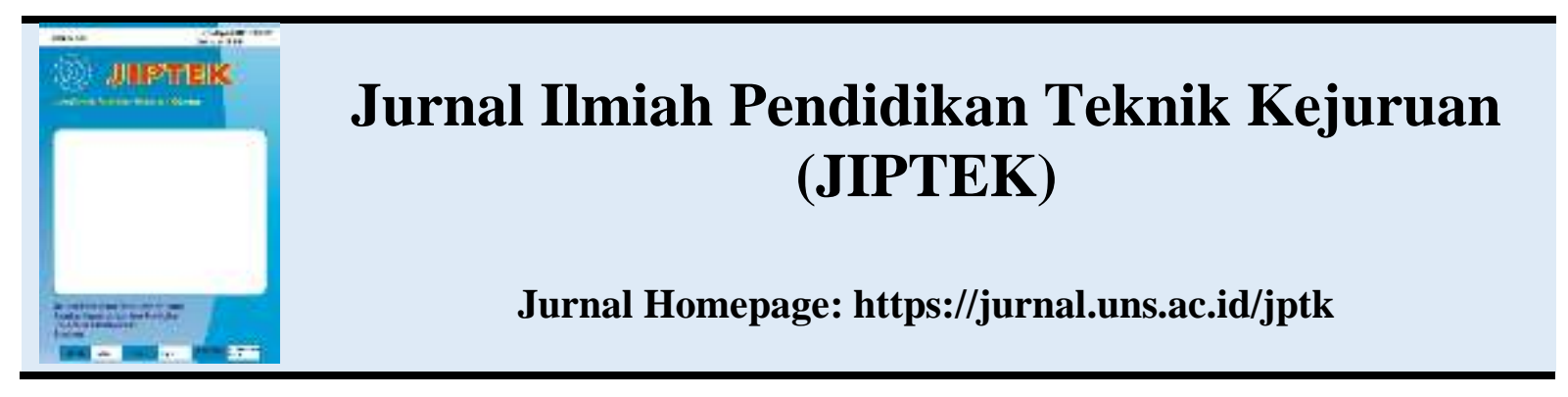

\title{
EFEKTIVITAS PENGGUNAAN E-LEARNING BERBASIS SCHOOLOGY DENGAN MENGGUNAKAN MODEL DISCOVERY LEARNING TERHADAP PRESTASI BELAJAR SISWA PADA MATA PELAJARAN SISTEM KOMPUTER KELAS X MULTIMEDIA SMK NEGERI 6 SURAKARTA PADA TAHUN PELAJARAN 2015/2016
}

\author{
${ }^{1}$ Kansha Isfaraini Huurun'ien, ${ }^{1}$ Agus Efendi, ${ }^{1}$ A. G. Tamrin \\ Program Studi Pendidikan Teknik Informatika dan Komputer, Universitas Sebelas Maret, \\ E-mail:kansha.ih@gmail.com
}

\begin{abstract}
The purpose of this study was to determine (1) differences in student achievement between the experimental class and control class which given a treatment the use of e-learning-based Schoology using discovery learning models; (2) the effectiveness of the use of e-learning-based Schoology using a model of discovery learning in improving student achievement. The population of this study was students of $X$ grade multimedia in SMK Negeri 6 Surakarta. The sampling technique that is used was random sampling. This research method is using quasi experimental. Data collection techniques in this study is using observational methods to determine the management of learning before and after treatments the use of e-learning-based schoology using a model of discovery learning. Methods of documentation to determine the list of names, the number of students, daily value and research evidence were taken by picture. The test method to determine the results of pretest and posttest. Analysis of the data used is non parametric test using the Mann Whitney test and the Wilcoxon signed rank test. Based on this research, first, there is a difference between the posttest value between control class and the experimental class after being given treatment such as the use of e-learning-based schoology using discovery learning models, sig value is smaller than the significance level 0,05 which is 0,000<0.05. Second, the use of e-learning based schoology using discovery learning is more effective, with an increase in the value of gain of 0,94. While conventional learning provides increased in the value of gain of 0,74 .
\end{abstract}

Keywords: Effectiveness, E-learning, Schoology, Model discovery learning, student achievement

\section{Abstrak}

Tujuan dari penelitian ini adalah untuk mengetahui (1) perbedaan prestasi belajar siswa antara kelas kontrol dengan kelas eksperimen yang diberikan treatment penggunaan e-learning berbasis schoology dengan menggunakan model discovery learning; (2) efektivitas penggunaan e-learning berbasis schoology dengan menggunakan model discovery learning dalam meningkatkan prestasi belajar siswa. Populasi penelitian ini adalah siswa kelas X multimedia SMK Negeri 6 Surakarta. Teknik pengambilan sampel yang digunakan random sampling. Metode penelitian ini menggunakan quasi eksperimental. Teknik pengumpulan data pada penelitian ini menggunakan metode observasi untuk mengetahui pengelolaan pembelajaran sebelum dan sesudah diberikan treatmen penggunaan e-learning berbasis schoology dengan menggunakan model discovery learning. Metode dokumentasi untuk mengetahui daftar nama, jumlah siswa, nilai harian serta bukti penelitian dengan menggunakan pengambilan gambar. Metode tes untuk mengetahui hasil pretest dan posttest. Analisis data yang digunakan uji non parametrik menggunakan mann whitney test dan wilcoxon sign rank test. Berdasarkan 
hasil penelitian, pertama terdapat perbedaan nilai posttest antara kelas kontrol dan kelas eksperimen setelah diberikan treatment berupa penggunaan e-learning berbasis schoology menggunakan model discovery learning, nilai sig lebih kecil dari taraf signifikan 0,05 yaitu $0,000<0,05$. Kedua penggunaan e-learning berbasis schoology menggunakan model discovery learning lebih efektif, dengan peningkatan nilai gain sebesar 0,94. Sedangkan pembelajaran konvensional memberikan peningkatan nilai gain sebesar 0,74.

Kata kunci : Efektivitas, E-learning, Schoology, Model discovery learning, Prestasi belajar siswa

\section{Pendahuluan}

Latar Belakang

Pada zaman yang semakin berkembang, pada saat ini sistem pembelajaran tidak hanya dilakukan menggunakan model ceramah, namun pembelajaran juga dapat dilakukan secara jarak jauh dan dapat dilakukan diluar jam pelajaran sekolah menggunakan sistem $E$ Learning. Menurut Hartley (2001), E-Learning merupakan suatu jenis belajar mengajar yang memungkinkan tersampaikannya bahan ajar ke siswa dengan menggunakan media Internet, Intranet atau media jaringan komputer lain.

Kurikulum yang digunakan oleh SMK Negeri 6 Surakarta pada saat ini adalah Kurikulum 2013, dimana Kurikulum tersebut guru tidak menjadi Teacher Center dan siswa dituntut aktif dalam pembelajaran. Namun pada kenyataanya siswa belum bisa berperan aktif dalam pembelajaran. Hal tersebut bisa dilihat dari siswa yang lulus KKM adalah 50\% baik kelas X MM 1 maupun X MM 2 dan rata-rata nilai kedua kelas tersebut masih dibawah KKM, hal tersebut dikarena nilai siswa yang lulus KKM hanya berkisar 76 sampai dengan 78 . Selain itu, komunikasi yang terjalin antara guru dan siswapun terbilang sangat kurang. Hal itu disebabkan karena siswa yang enggan untuk bertanya langsung kepada guru di dalam kelas. Oleh karena itu, media e-learning berbasis schoology sangat cocok apabila digunakan pada kurikulum 2013 guna untuk membuat siswa menjadi lebih aktif dalam belajar dan siswapun bisa menggunakan fasilitas private message dengan guru untuk menjalin komunikasi diluar jam pelajaran.

Media e-learning juga membutuhkan dukungan dari model pembelajaran yang cocok untuk dikolaborasikan dan ditetapkan model yang digunakan adalah model discovery learning. Menurut Hanafiah dan Suhana (2012: 77), discovery learning merupakan suatu rangkaian kegiatan pembelajaran yang melibatkan secara maksimal seluruh kemampuan siswa untuk mencari dan menyelidiki secara sistematis, kritis, dan logis sehingga mereka dapat menemukan sendiri pengetahuan, sikap, dan keterampilan sebagai wujud adanya perubahan perilaku. Melalui penerapan media e-learning berbasis schoology dengan menggunakan model discovery learning diharapkan dapat meningkatkan prestasi belajar siswa pada mata pelajaran sistem komputer.

\section{Rumusan Masalah}

1. Apakah terdapat perbedaan prestasi belajar siswa antara kelas kontrol dan kelas eksperimen dengan treatment penggunaan e-learning berbasis schoology dengan menggunakan discovery learning pada mata pelajaran sistem komputer kelas $\mathrm{X}$ Multimedia di SMK Negeri 6 Surakarta?

2. Apakah penggunaan e-learning berbasis schoology dengan menggunakan model discovery learning lebih efektif dalam meningkatkan prestasi belajar siswa pada mata pelajaran sistem komputer kelas $\mathrm{X}$ multimedia SMK Negeri 6 Surakarta?

Tujuan Penelitian

1. Untuk menguji ada tidanya perbedaan prestasi belajar siswa antara kelas kontrol dan kelas eksperimen dengan treatment penggunaan e-learning berbasis schoology dengan menggunakan discovery learning pada mata pelajaran sistem komputer kelas X Multimedia di SMK Negeri 6 Surakarta.

2. Untuk menguji efektif tidaknya penggunaan e-learning berbasis schoology dengan menggunakan model discovery learning dalam meningkatkan prestasi belajar siswa pada mata pelajaran sistem komputer kelas $\mathrm{X}$ multimedia SMK Negeri 6 Surakarta.

Kajian Pustaka

Menurut Mishadin (2012: 7) efektivitas berarti ada efeknya (akibat, pengaruhnya, 
kesannya), manjur atau mujarab dan dapat membawa hasil. Sedangkan menurut Abdurahmat (2003: 92) efektivitas adalah pemanfaatan sumber daya, sarana dan prasarana dalam jumlah tertentu yang secara sadar ditetapkan sebelumnya untuk menghasilkan sejumlah pekerjaan tepat pada waktunya.

Stockley dalam Prawiradilaga (2013: 33) mendefinisikan e-learning sebagai penyampaian program pembelajaran, pelatihan, atau pendidikan dengan menggunakan sarana elektronik seperti komputer atau alat elektronik lain seperti telepon genggam dengan berbagai cara untuk memberikan pelatihan, pendidikan atau bahan ajar

Schoology merupakan salah satu platform inovatif yang dibangun berdasarkan inspirasi dari media sosial facebook dengan tujuan untuk kepentingan pendidikan. Menurut Maharani dalam juniarti (2014: 16), dengan menggunakan schoology guru dapat mengasah pola pikir peserta didik untuk berfikir secara kritis dan kreatif.

Hanafiah dan Suhana (2012: 77), discovery learning merupakan suatu rangkaian kegiatan pembelajaran yang melibatkan secara maksimal seluruh kemampuan siswa untuk mencari dan menyelidiki secara sistematis, kritis, dan logis sehingga mereka dapat menemukan sendiri pengetahuan, sikap, dan keterampilan sebagai wujud adanya perubahan perilaku.

Sudjana (1991: 22) prestasi belajar adalah kemampuan yang dimiliki siswa setelah ia menerima pengalaman belajar.

Berdasarkan dari hasil penelitian yang relevan oleh Ramdhani (2012), bahwa efektivitas penggunaan media pembelajaran $E$ Learning berbasis web lebih tinggi daripada menggunakan media pembelajaran konvensional. Selain itu, penelitian yang relevan lainnya oleh Rahmalia (2014), bahwa terdapat perbedaan hasil pada ranah afektif dan ranah kognitif antara siswa eksperimen yang menggunakan model discovery learning dengan siswa kelas kontrol.

\section{Metode Penelitian}

Metode penelitian yang digunakan dalam penelitian ini adalah metode quasi experimental design. Adapun rencana desain penelitian secara umum dapat digambarkan seperti berikut:
Tabel 1. Rencana desain penelitian secara umum

\begin{tabular}{|c|c|c|c|}
\hline Kelomipok & Protest & Perlakuan & Posmest \\
\hline KE & $\mathrm{KE}_{1}$ & $\mathrm{x}_{1}$ & $\mathrm{KEI}$ \\
\hline KK & $\mathrm{KK}:$ & $\mathrm{X}_{2}$ & $\mathrm{KK}_{2}$ \\
\hline
\end{tabular}

Keterangan:

$$
\begin{aligned}
\mathrm{KE}= & \text { Kelas Eksperimen } \\
\mathrm{KK}= & \text { Kelas Kontrol } \\
\mathrm{KE}_{1}= & \text { Kemampuan kelas eksperimen } \\
& \text { sebelum diberi perlakuan } \\
\mathrm{KE}_{2}= & \begin{array}{l}
\text { Kemampuan kelas eksperimen } \\
\text { sesudah diberi perlakuan }
\end{array} \\
\mathrm{KK}_{1}= & \begin{array}{l}
\text { Kemampuan kelas kontrol } \\
\text { sebelum diberi perlakuan }
\end{array} \\
\mathrm{KK}_{2}= & \begin{array}{l}
\text { Kemampuan kelas kontrol } \\
\text { sesudah diberi perlakuan }
\end{array} \\
\mathrm{X}_{1}= & \begin{array}{l}
\text { Perlakuan menggunakan } \\
\text { learning berbasis schoology } \\
\text { dengan model discovery learning }
\end{array} \\
\mathrm{X}_{2}= & \begin{array}{l}
\text { Perlakuan menggunakan } \\
\text { pembelajaran konvensional }
\end{array}
\end{aligned}
$$

Populasi dalam penelitian ini adalah siswa kelas X Multimedia SMK Negeri 6 Surakarta pada tahun pelajaran 2015/2016. sampel yang digunakan dalam penelitian ini kelas X multimedia 1 sebagai kelas kontrol dan $\mathrm{X}$ multimedia 2 sebagai kelas eksperimen dengan jumlah 64 siswa. Teknik pengambilan sampel pada penelitian ini menggunakan teknik random sampling.

Adapun metode pengumpulan data yang digunakan pada penelitian ini adalah sebagai berikut:

1. Metode Observasi

2. Metode Dokumentasi

3. Metode Tes

Pengujian hipotesis pada penelitian ini menggunakan statistik non parametrik. Uji hipotesis yang digunakan adalah sebagai berikut:

1. Mann Withney Test

2. Wilcoxon Sign Rank Test

3. Standart Gain

\section{Hasil dan Pembahasan}

Berdasarkan hasil pretest yang diperoleh kelas X Multimedia 2 (kelas eksperimen) dengan jumlah 32 siswa didapatkan nilai tertingginya adalah 73,91 dan nilai terendahnya 
adalah 4,34. Sedangkah hasil pretest yang diperoleh kelas X Multimedia 1 (kelas kontrol) dengan jumlah 32 siswa didapatkan nilai tertingginya adalah 60,86 dan nilai terendahnya adalah 43,34.

Berdasarkan hasil posttest yang diperoleh kelas $\mathrm{X}$ Multimedia 2 (kelas eksperimen) dengan jumlah 32 siswa didapatkan nilai tertingginya adalah 100 dan nilai terendahnya adalah 78,26. Sedangkah hasil posttest yang diperoleh kelas $\mathrm{X}$ Multimedia 1 (kelas kontrol) dengan jumlah 32 siswa didapatkan nilai tertingginya adalah 100 dan nilai terendahnya adalah 30,43.

Berdasarkan hasil belajar siswa yaitu pretest dan posttest, didapatkan peningkatan hasil belajar. Berikut distribusi peningkatan hasil belajar siswa dalam bentuk nilai absolute gain dan standart gain dari kelas eksperimen dan kelas kontrol yang telah disajikan dalam bentuk tabel.

Tabel 2 Peningkatan Hasil Belajar Siswa (Standart Gain)

\begin{tabular}{lccccc}
\hline Kelas & $\begin{array}{c}\text { Rata- } \\
\text { rata } \\
\text { Pretest }\end{array}$ & $\begin{array}{c}\text { Rata- } \\
\text { rata } \\
\text { Pestest }\end{array}$ & $\begin{array}{c}\text { Absolut } \\
\text { Gain }\end{array}$ & $\begin{array}{c}\text { Siandart } \\
\text { Gain }\end{array}$ & Seterwingan \\
\hline Eksperimen & 36,67 & 96,47 & 59,80 & 0,94 & TINGGI \\
Kontrol & 28,11 & 81,79 & 53,68 & 0,74 & TINGGI \\
\hline
\end{tabular}

Hasil Uji Prasyarat Analisis

\section{Uji Normalitas}

Tujuan dari uji normalitas untuk meneguji normal atau tidaknya data yang dianalisis. Data dinyatakan berdistribusi normal apabila nilai probabilitas $(\mathrm{sig})>$ taraf signifikan $\propto=0,05$ sedangkan apabila nilai probabilitas $($ sig $)<$ taraf signifikan $\propto=0,05$ maka data berdistribusi tidak normal. Berikut uji normalitas yang disajikan dalam bentuk tabel.

Tabel 3 Hasil Uji Normalitas Kelas Eksperimen dan Kelas Kontrol

\begin{tabular}{|c|c|c|c|c|}
\hline Data & Hasil Belajar & sig & $\begin{array}{c}\text { Taraf } \\
\text { Siginifikan }\end{array}$ & Keterangan \\
\hline Bretest & $\begin{array}{l}\text { Eksperimen } \\
\text { Kontrol }\end{array}$ & $\begin{array}{l}0,006 \\
0,003\end{array}$ & \multirow[b]{2}{*}{0,05} & IID \\
\hline Postest & $\begin{array}{l}\text { Ekperimen } \\
\text { Kontrol }\end{array}$ & $\begin{array}{l}0,000 \\
0,015\end{array}$ & & $\begin{array}{l}\text { TIDAK NORMAL } \\
\text { TIDAK NORMAL }\end{array}$ \\
\hline
\end{tabular}

\section{Uji Homogenitas}

Tujuan dari uji homogenitas untuk mengetahui apakah data kelas eksperimen dan kelas kontrol yang dianalisis bersifat homogen atau tidak serta sampel berasal dari populasi yang homogen atau tidak. Data dinyatakan berdistribusi homogen apabila nilai sig $>$ taraf signifikan $\propto=0,05$ sedangkan apabila nilai sig $<$ taraf signifikan $\propto=0,05$ maka data berdistribusi tidak normal. Berikut uji homogenitas dari pretest dan posttest yang disajikan dalam bentuk tabel.

Tabel 4 Hasil Homogenitas Kelas Eksperimen dan Kelas Kontrol

\begin{tabular}{cccc}
\hline Data & sig & Taraf Siguifikan & Keterangan \\
\hline Protest & 0,775 & 0,05 & HOMOGEN \\
\cline { 1 - 1 } Pestiest & 0,000 & & TIDAK HOMOGEN \\
\hline
\end{tabular}

Hasil Uji Hipotesis

Berdasarkan uji normalitas yang disajikan pada tabel 3 memberikan hasil data dari pretest dan posttest pada kelas eksperimen maupun kelas kontrol berdistribusi tidak normal dan uji homogenitas yang disajikan pada tabel 4 memberikan hasil data dari pretest pada kelas eksperimen dan kelas kontrol berdistribusi homogen sedangkan posttest kelas eksperimen dan kelas kontrol berdistribusi tidak homogen. Oleh karena itu, pada pengujian hipotesis pada penelitian ini menggunakan statistik non parametrik. Untuk uji hipotesis pertama menggunakan uji mann withney test. Uji hipotesis kedua menggunakan uji wilcoxon sign rank test.

\section{Uji Hipotesis 1}

Uji hipotesis pertama adalah uji data pretest, bertujuan untuk mengetahui apakah terdapat perbedaan atau tidak kemampuan awal (pretest) antara kelas eksperimen dan kelas kontrol. Kriteria pengujian yang digunakan pada uji ini adalah jika sig $>0,05$ maka $\mathrm{H}_{0}$ diterima dan $\mathrm{H}_{1}$ ditolak. Sedangkan jika sig $<$ 0,05 maka $\mathrm{H}_{0}$ ditolak dan $\mathrm{H}_{1}$ diterima. $\mathrm{H}_{0}$ pada uji ini memberikan arti tidak ada perbedaan nilai pretest antara kelas eksperimen dan kelas kontrol. Sedangkan $\mathrm{H}_{1}$ memberikan arti terdapat perbedaan nilai pretest antara kelas eksperimen dan kelas kontrol. Dibawah ini rangkuman hasil uji hipotesis untuk kemampuan awal (pretest) yang disajikan dalam bentuk tabel.

Tabel 5 Rangkuman Hasil Hipotesis Pretest

\begin{tabular}{lcccc}
\hline Kelompok & N & P (sig) & Taraf Signifikan & Keterangan \\
\hline $\begin{array}{l}\text { Eksperimen } \\
\text { Kostrol }\end{array}$ & 32 & 0,115 & 0,05 & $\begin{array}{l}\text { Ho DIIERIMA } \\
\text { Ho DIERIMA }\end{array}$ \\
\hline
\end{tabular}

Berdasarkan tabel di atas dapat dilihat bahwa $0,115>0,05$ maka $\mathrm{H}_{0}$ diterima dan $\mathrm{H}_{1}$ ditolak, dapat ditarik kesimpulan tidak ada 
perbedaan nilai pretest antara kelas eksperimen dan kelas kontrol. Artinya kemampuan awal (pretest) antara kelas eksperimen dan kelas kontrol sama.

Uji hipotesis selanjutnya yaitu uji data posttest, bertujuan untuk mengetahui apakah terdapat perbedaan atau tidak kemampuan akhir (posttest) antara kelas eksperimen dan kelas kontrol setelah diberikan treatment. Kriteria pengujian yang digunakan pada uji ini adalah

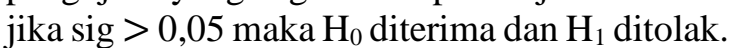
Sedangkan jika sig $<0,05$ maka $\mathrm{H}_{0}$ ditolak dan $\mathrm{H}_{1}$ diterima. $\mathrm{H}_{0}$ pada uji ini memberikan arti tidak ada perbedaan nilai posttest antara kelas eksperimen dan kelas kontrol. Sedangkan $\mathrm{H}_{1}$ memberikan arti terdapat perbedaan nilai posttest antara kelas eksperimen dan kelas kontrol. Dibawah ini rangkuman hasil uji hipotesis untuk kemampuan akhir (posttest) yang disajikan dalam bentuk tabel.

Tabel 6 Rangkuman Hasil Hipotesis Posttest

\begin{tabular}{|c|c|c|c|c|}
\hline Kelompok & $\mathrm{N}$ & $P$ (rie) & Taraf Signifikan & Keteraagan \\
\hline $\begin{array}{l}\text { Eksperimen } \\
\text { Koutrol }\end{array}$ & $\begin{array}{l}32 \\
32\end{array}$ & 0,000 & 0.05 & $\begin{array}{l}\mathrm{H}_{1} \text { DITERMLA } \\
\mathrm{H}_{1} \text { DIIERMMA }\end{array}$ \\
\hline
\end{tabular}

Berdasarkan tabel di atas dapat dilihat bahwa $0,000<0,05$ maka $\mathrm{H}_{0}$ ditolak dan $\mathrm{H}_{1}$ diterima. Maka dapat ditarik kesimpulan terdapat perbedaan nilai posttest antara kelas eksperimen dan kelas kontrol. Artinya kemampuan akhir (posttest) antara kelas eksperimen dan kelas kontrol tidak sama setelah kelas eskperimen diberikan treatment.

\section{Uji Hipotesis 2}

Pengujian data pretest-posttest kelas eksperimen bertujuan untuk mengetahui apakah ada perbedaan atau tidak nilai rata-rata sebelum dan sesudah treatment yang diberikan terhadap sampel. Treatment yang diberikan adalah pembelajaran e-learning berbasis schoology dengan menggunakan model discovery learning. Kriteria pengujian yang digunakan pada uji ini adalah jika sig $>0,05$ maka $\mathrm{H}_{0}$ diterima dan $\mathrm{H}_{1}$ ditolak. Sedangkan jika sig $<0,05 \mathrm{H}_{0}$ ditolak dan $\mathrm{H}_{1}$ diterima. $\mathrm{H}_{0}$ pada uji ini memberikan arti tidak ada perbedaan nilai rata-rata sebelum dan sesudah diberikan treatment pada kelas eksperimen. Sedangkan $\mathrm{H}_{1}$ memberikan arti terdapat perbedaan nilai rata-rata sebelum dan sesudah diberikan treatment pada kelas eksperimen. Dibawah ini rangkuman hasil uji hipotesis untuk pretest-posttest yang disajikan dalam bentuk Tabel.
Tabel 7 Rangkuman Hasil Hipotesis PretestPosttest Kelas Eksperimen

\begin{tabular}{ccccc}
\hline Data & N & P (rig) & Taraf Signifikan & Keterangan \\
\hline Protest & 32 & 0,000 & 0,05 & H 1 DITERIMA \\
Postrest & 32 & & & H DITERIMA \\
\hline
\end{tabular}

Berdasarkan tabel di atas dapat dilihat bahwa $0,000<0,05$ maka $\mathrm{H}_{0}$ ditolak dan $\mathrm{H}_{1}$ diterima. Maka dapat ditarik kesimpulan terdapat perbedaan nilai rata-rata sebelum dan sesudah diberikan treatment pada kelas eksperimen.

Pengujian selanjutnya yaitu pengujian data pretest-posttest kelas kontrol bertujuan untuk mengetahui apakah ada perbedaan atau tidak nilai rata-rata sebelum dan sesudah diberikan pembelajaran media penyimpanan data eksternal pada kelas kontrol. Kriteria pengujian yang digunakan pada uji ini adalah jika sig $>0,05$ maka $\mathrm{H}_{0}$ diterima dan $\mathrm{H}_{1}$ ditolak. Sedangkan jika sig $<0,05 \mathrm{H}_{0}$ ditolak dan $\mathrm{H}_{1}$ diterima. $\mathrm{H}_{0}$ pada uji ini memberikan arti tidak ada perbedaan nilai rata-rata sebelum dan sesudah diberikan pembelajaran pada kelas kontrol. Sedangkan $\mathrm{H}_{1}$ memberikan arti terdapat perbedaan nilai rata-rata sebelum dan sesudah diberikan pembelajaran pada kelas kontrol. Dibawah ini rangkuman hasil uji hipotesis pretest-posttest yang disajikan dalam bentuk tabel.

Tabel 8 Rangkuman Hasil Hipotesis PretestPosttest Kelas Kontrol

\begin{tabular}{ccccc}
\hline Data & N & P (sig) & Taraf Signifikan & Keterangan \\
\hline Pretest & 32 & 0,000 & 0,05 & Hi DITERIMA \\
Posttest & 32 & & & Hi DITERIMA \\
\hline
\end{tabular}

Berdasarkan tabel di atas dapat dilihat bahwa $0,000<0,05$ maka $\mathrm{H}_{0}$ ditolak dan $\mathrm{H}_{1}$ diterima. Maka dapat ditarik kesimpulan terdapat perbedaan nilai rata-rata sebelum dan sesudah diberikan pembelajaran pada kelas kontrol.

Pembahasan

Perbedaan Prestasi Belajar Siswa Pada Mata Pelajaran Sistem Komputer Kelas X Multimedia Di SMK Negeri 6 Surakarta Antara Kelas Eksperimen Dan Kelas Kontrol

Perbedaan prestasi belajar siswa pada penelitian ini ditinjau dari data hasil pretest dan posttest pada kelas eksperimen dan kelas kontrol. Diketahui rata-rata nilai pretest kelas eksperimen yaitu 36,67 sedangkan rata-rata nilai pretest kelas kontrol yaitu 28,11 . Setelah dilakukan uji hipotesis non parametrik 
menggunakan uji man withney test didapatkan hasil nilai sig lebih besar dari taraf signifikan 0,05. Maka dapat ditarik kesimpulan kemampuan awal (pretest) antara kelas eksperimen dan kelas kontrol sama.

Hasil pretest kelas eksperimen dengan presentase paling tinggi berada pada interval 16,36 - 22,36 yaitu $31 \%$ dan presentase paling rendah berada di interval 52,42 - 58,42 dan $70,45-76,45$ yaitu sebesar $3 \%$. Sedangkan hasil pretest kelas kontrol presentase paling tinggi berada pada interval 16,36 - 22,36 sebesar $35 \%$ dan presentase paling rendah pada interval 22,37 - 28,37 yaitu sebesar 3\%.

Prestasi belajar siswa juga ditinjau dari hasil nilai posttest pada siswa kelas eksperimen dan kelas kontrol. Diketahui rata-rata nilai posttest pada kelas eksperimen setelah mendapatkan treatment yaitu 96,47 sedangkan nilai rata-rata posttest pada kelas kontrol yaitu 81,79. Dapat dilihat dari nilai rata-rata posttest kelas eksperimen mengalami peningkatan lebih tinggi dibandingkan kelas kontrol. Setelah dilakukan uji hipotesis non parametrik menggunakan uji man withney test didapatkan hasil nilai sig lebih kecil dari taraf signifikan 0,05. Maka dapat ditarik kesimpulan kemampuan akhir (posttest) antara kelas eksperimen dan kelas kontrol tidak sama setelah kelas eskperimen diberikan treatment.

Hasil posttest kelas eksperimen sebagian besar memiliki presentase pada interval 96,54101,54 yaitu sebesar $63 \%$ dan presentase terendah berada di interval 72,50 - 78,50 dan 84,51 - 90,52 sebesar 3\%. Sedangkan hasil posttest kelas kontrol hanya mendapatkan $25 \%$ presentase paling tinggi pada interval 96,54 101,54 dan presentase paling rendah berada pada 5 interval yaitu, 30,43 - 36,43, 42,45 $48,45,48,46$ - 54,46, 54,47 - 60,47, 84,51 90,52 sebesar 3\%. Dari data tersebut membuktikan bahwa siswa kelas eksperimen mengalami peningkatan prestasi belajar dibandingkan dengan siswa kelas kontrol, peningkatan prestasi belajar siswa kelas eksperimen sebesar 59,80 sedangkan pada kelas kontrol 53,68.

Efektivitas E-Learning Berbasis Schoology Dengan Menggunakan Model Discovery Learning Meningkatkan Prestasi Belajar Siswa Pada Mata Pelajaran Sistem Komputer Kelas X Multimedia Di SMK Negeri 6 Surakarta

Efektivitas penggunaan e-learning berbasis schoology dengan menggunakan model discovery learning dapat dilihat dari hasil rata-rata pretest-posttest kelas eksperimen dan kelas kontrol. Selain itu efektivitas penggunaan e-learning berbasis schoology dengan menggunakan model discovery learning juga dapat dilihat dari uji hipotesis menggunakan uji wilcoxon sign rank test. Berdasrkan hasil rata-rata nilai pretest kelas eksperimen yaitu 36,67 sedangkan hasil ratarata nilai posttest setelah menerima treatment yaitu 96,47 . Nilai sig yang diperoleh dari uji hipotesis 2 lebih kecil dari taraf signifikan 0,05. Sedangkan nilai rata-rata pretest pada kelas kontrol sebesar 28,11 dan nilai posttest sebesar 81,79 . Nilai sig yang diperoleh kelas kontrol pada hipotesis 2 juga mendapatkan hasil lebih kecil dari pada taraf signifikan 0,05. Sehingga dapat ditarik kesimpulan terdapat perbedaan nilai rata-rata sebelum dan sesudah diberikan teartemen pada kelas eksperimen dan pembelajaran konvensional pada kelas kontrol. Akan tetapi meskipun kedua kelas tersebut mengalami perbedaan yang signifikan sebelum dan sesudah diberikan treatment, kelas eksperimen memberikan peningkatan nilai gain lebih tinggi dibandingkan dengan kelas kontrol. Kelas eksperimen mengalami peningkatan nilai gain sebesar 0,94 sedangkan kelas kontrol mengalami peningkatan nilai gain sebesar 0,74. Di bawah ini adalah rangkuman rata-rata prestasi belajar siswa kelas eksperimen (KE) dan kelas kontrol (KK) yang disajikan pada gambar.

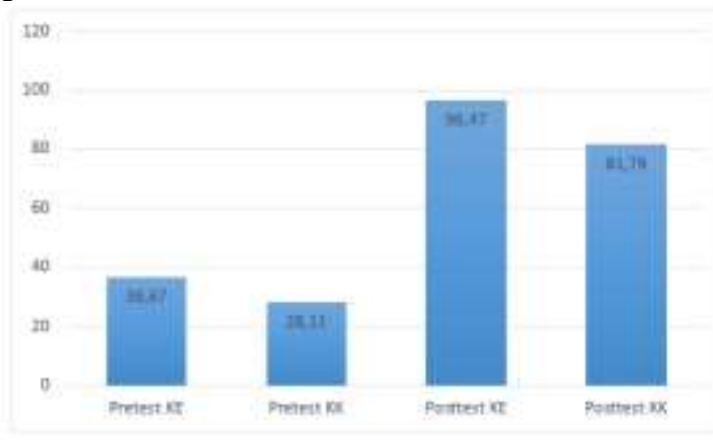

Gambar 1 Rata-rata Prestasi Belajar Siswa

Berdasarkan gambar di atas, terlihat apabila nilai pretest dan posttet kelas eksperimen mengalami peningkatan. Berdasarkan data-data yang diperoleh di atas, maka dapat ditarik kesimpulan apabila penggunaa e-learning berbasis schoology dengan menggunakan model discovery learning pada kelas eksperimen efektif.

Menurut Indrayasa, Agung \& Mahadewi (2015) pada e-journal Edutech Universitas 
Pendidikan Ganesha dengan judul "Pengembangan E-Learning Dengan Schoology Pada Mata Pelajaran Bahasa Indonsia Untuk Siswa Kelas X Semester I Tahun Pelajaran 2014/2015 Di SMA N 4 Singaraja" memberikan hasil bahwa media $e$ learning berbasis schoology terbukti efektif secara signifikan dapat meningkatkan hasil belajar mata pelajaran Bahasa Indonesia Kelas X semester I tahun pelajaran 2014/2015 di SMA Negeri 4 Singaraja.

\section{Simpulan dan Saran}

Simpulan

Berdasarkan hasil dari penelitian yang dilakukan di SMK Negeri 6 Surakarta pada akhir bulan April sampai awal Mei 2016 mengenai efektivitas penggunaan $e$ learning berbasis schoology dengan menggunakan model discovery learning terhadap peningkatan prestasi belajar siswa kelas X multimedia SMK Negeri 6 Surakarta pada mata pelajaran sistem komputer dapat di tarik kesimpulan sebagai berikut :

1. Terdapat perbedaan nilai posttest antara kelas kontrol dan kelas eksperimen setelah diberikan treatment berupa penggunaan e-learning berbasis schoology menggunakan model discovery learning, nilai sig lebih kecil dari taraf signifikan 0,05 yaitu $0,000<0,05$.

2. Penggunaan e-learning berbasis schoology menggunakan model discovery learning lebih efektif, dengan peningkatan nilai gain sebesar 0,94. Sedangkan pembelajaran konvensional memberikan peningkatan nilai gain sebesar 0,74 .

Saran

Berdasrkan hasil penelitian yang dilakukan di SMK Negeri 6 Surakarta mengenai efektivitas penggunaan e-learning berbasis schoology dengan menggunakan model discovery learning terhadap peningkatan prestasi belajar siswa kelas X multimedia SMK Negeri 6 Surakarta pada mata pelajaran sistem komputer, dapat diajukan saran bagi semua pihak antara lain :

1. Siswa hendaknya lebih aktif pada saat pelajaran berlangsung.

2. Siswa hendaknya mampu melakukan pembelajaran dimanapun dan kapanpun menggunakan e-learning berbasis schoology.
3. Guru hendaknya dapat menerapkan penggunaan $e$-leraning berbasis schoology dengan menggunakan model discovery learning guna untuk meningkatkan prestasi belajar siswa.

4. Guru juga dapat memafaatkan e-learning berbasis schoology untuk mengoptimalkan materi pembelajaran yang sangat banyak.

5. Guru dan siswa hendaknya lebih mudah berkomunikasi diluar jam pelajaran.

\section{Daftar Pustaka}

Abdurahmat. (2003). Efektivitas Organisasi, edisi Pertama. Jakarta: Erlangga.

Hanafiah \& Suhana, C. (2012). Konsep Startegi Pembelajaran. Bandung: PT. Refika Aditama.

Hartley, D. E. (2001). Selling E-Learning. American Society For Training And Development.

Indrayasa, K, B., Agung, A, A, G., \& Mahadewi, L, P, P. (2015). Pengembangan E-Learning Dengan Schoology Pada Mata Pelajaran Bahasa Indonesia Untuk Siswa Kelas X Semester I tahun Pelajaran 2014/2015 Di SMA N 4 Singaraja. E-Journal Edutech Universitas Pendidikan Ganesha. 3(1).

Juniarti, R.D. (2014). Pengembangan Media Mobile Learning Dengan Aplikasi Schoology Pada Pembelajaran Geografi Materi Hidrosfer Kelas X SMA Negeri 1 Karanganyar. Skripsi Tidak Dipublikasikan. Universitas Sebelas Maret, Surakarta.

Mishadin. (2012). Efektivitas Media Pembelajaran Berbasis Komputer Pada Mata pelajaran Elektronika Terhadap Prestasi Belajar Siswa Kelas XI di SMK 1 Sedayu Bantul. Skripsi Tidak Dipubikasikan. Universita Negeri Yogyakarta, Yogyakarta.

Prawiradilaga, D.S., Ariani, D., \& Handoko, H. (2013). Mozaik Teknologi Pendidikan ELearning. Jakarta: Prenamedia Group.

Rahmalia, Y. (2014). Efektivitas Model Discovery Learning Untuk Peningkatan Hasil Belajar Siswa Kelas X Pada Kompetensi Dasar Analisis Rangkaian Kemagnetan Di SMK 1 Pundong. Skripsi 
Tidak Dipublikasi. Universitas Negeri Yogyakarta, Yogyakarta.

Ramdhani, M. (2012). Efektivitas Penggunaan Media Pembelajaran E-Learning Berbasis Web Pada Pelajaran Teknologi Informasi dan Komunikasi Terhadap Hasil Belajar Siswa Kelas X SMA Negeri
1 kalasan. Skripsi Tidak Dipublikasikan. Universitas Negeri Yogyakarta, Yogyakarta.

Sudjana, N. (1991). Dasar - Dasar Proses Belajar Mengajar. Bandung: PT. Remaja Rosdakarya. 